Volume 7 No. 1, Juni 2020

P-ISSN: 2406-808X // E-ISSN: 2550-0686

https://journal.iainlangsa.ac.id/index.php/ikhtibar

https://doi.org/10.32505/ikhtibar.v7i1.613

\title{
MOTIVASI SANTRIWATI DAYAH SALAFIYAH BIREUEN MELANJUTKAN PENDIDIKAN KE PERGURUAN TINGGI
}

\author{
Rafidhah Hanum, Fakhrul Rijal \\ UIN Ar-Raniry Banda Aceh \\ rafidhahhanum89@gmail.com
}

\begin{abstract}
Abstrak
Permasalahan dalam penelitian ini adalah santriwati dayah salafiyah yang belum menempuh pendidikan di perguruan tinggi, sering diasumsikan sebagai kaum yang menutup diri dan cenderung apatis terhadap kemajuan ilmu pengetahuan dan teknologi. Tujuan dari penelitian ini adalah untuk mengetahui motivasi santri dayah dalam melanjutkan pendidikan ke perguruan tinggi. Untuk mengetahui bagaimana persepsi santri terhadap perguruan tinggi dan untuk mengetahui dorongan dan tantangan santri dayah salafiyah Bireuen untuk melanjutkan pendidikan ke perguruan tinggi. Penelitian ini menggunakan metode kualitatif dengan pendekatan deskriptif analisis. Temuan dalam penelitian ini adalah motivasi santri dayah dalam melanjutkan pendidikan ke perguruan tinggi sebenarnya sangat antusias dikarenakan pendidikan di perguruan tinggi dapat menambah khazanah keilmuan seiring dengan tuntutan kemajuan zaman. Ada beberapa faktor yang dapat mendukung dan menghambat santriwati dalam melanjutkan pendidikan ke perguruan tinggi. Di antara faktor pendukungnya adalah adanya dukungan dan anjuran dari pimpinan untuk melanjutkan pendidikan ke perguruan tinggi. Dukungan dari orang tua dan keluarga terutama dalam bidang materil juga merupakan faktor pendukung bagi santri untuk melanjutkan pendidikan ke perguruan tinggi. Adapun yang menjadi faktor penghambat bagi santriwati dalam melanjutkan pendidikan ke perguruan tinggi adalah kekurangan ekonomi, usia yang lanjut dan pemikiran santriwati sendiri yang telah mengikat pemikirannya untuk berkembang dan maju.
\end{abstract}

Kata Kunci: Motivasi Santriwati Dayah Salafiyah, Perguruan Tinggi

\section{Pendahuluan}

Istilah zawiyah, yang secara literal bermakna sudut, diyakini oleh masyarakat Aceh pertama kali digunakan sudut mesjid Madinah ketika Nabi Muhammad saw berdakwah pada masa awal Islam. Pada abad pertengahan, kata zawiyah difahami sebagai pusat agama dan kehidupan mistik dari penganut tasawuf, karena itu, didominasi hanya oleh ulama perantau, yang telah dibawa ke tengah-tengah masyarakat. Kadang-kadang lembaga ini dibangun menjadi sekolah agama dan pada saat tertentu juga zawiyah dijadikan sebagai pondok bagi pencari kehidupan spiritual. Sangat 
mungkin bahwa disebarkan ajaran Islam di Aceh oleh para pendakwah tradisional Arab dan sufi; Ini mengidentifikasikan bagaimana zawiyah diperkenalkan di Aceh. ${ }^{1}$

Dalam perkembangannya, agama Islam terus mengalami kemajuan dan begitu mengakar dalam masyarakat melalui peran dan perjuangan para ulama. Hal ini dilakukan bersama lembaga pendidikan yang dibangun, diasuh dan dibinanya, yakni dayah. Lembaga pendidikan ini di samping berperan sebagai tempat pembelajaran dan mendidik kader ulama dan masyarakat Aceh secara berkesinambungan juga berperan besar sebagai lembaga sosial kemasyarakatan yang banyak memberikan jasa dan prakarsa bagi pemberdayaan masyarakat sekitarnya. Ini terbukti bahwa tidak saja pada masa lampau, namun sampai saat ini alumni dayah bukan hanya berperan sebagai pendidik tetapi juga sebagai tokoh panutan masyarakat.Secara historis, santri dayah di Aceh tidak bisa dipisahkan dari berbagai kisah tentang kebesaran Aceh di masa lalu. Santri Aceh telah memberikan andil besar dalam berbagai proses pembangunan Aceh. Dengan dayah yang mengayominya, para santri menjadi benteng Aceh dari penetrasi penjajahan asing, baik penjajahan sosial budaya maupun penjajahan secara militer.

Santri juga memiliki andil besar dalam membangun nasionalisme keacehan dalam bingkai keislaman dalam upaya mengusir para penjajah. Artinya, kekuatan santri Aceh dalam peta gerakan di Aceh khususnya dan tanah air umumnya sangatlah diperhitungkan.

Dewasa ini, meskipun potensi yang dimiliki oleh santri di Aceh dinilai banyak kalangan masih belum tereksplorasi dan termanfaatkan dengan baik dalam membangun bangsa, dan meskipun keberadaan dayah cenderung dianggap sebagai lembaga pendidikan non formal, namun kiprah dan partisipasi santri dayah Aceh dewasa ini terus mengalami perkembangan yang signifikan. Dilihat dari segi kemajuan sekarang ini, dimana para santri sekarang ini telah berduyun-duyun dalam melanjutkan pendidikan ke perguruan tinggi, ada juga yang sudah berhasil berkiprah di instansi pemerintahan maupun di bidang lain.

Para santri sekarang ini berpikir bahwa, perlu nya membuka cakrawala dan paradigma berpikir baru yang lebih open dan rasional terhadap kondisi real duniawi. Oleh karena itu, mereka mengajak umat Islam untuk merenung bahwa dari satu sisi, agama dalam konteks apapun merupakan sebuah kemutlakan di atmosfir dunia global yang semakin tidak terbendung ini. Tapi dari sisi lain nilai-nilai filosofis agama ternyata mampu mengakomodir laju perubahan zaman sedrastis apapun. Justru itu, perlunya melanjutkan pendidikan di wadah yang lain salah satunya di perguruan tinggi, guna untuk memperdalam ilmu pengetahuan dan teknologi yang biasa dikenal dengan istilah "IPTEK", sebagai mana firman Allah swt yang terdapat dalam Al-Qur'an surat ArRahman ayat 33 adalah sebagai berikut:

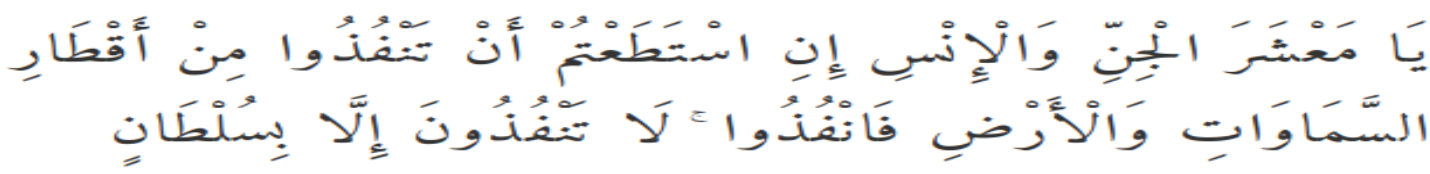

Artinya:

"Hai jama'ah jin dan manusia, jika kamu sanggup menembus (melintasi) penjuru langit dan bumi, Maka lintasilah, kamu tidak dapat menembusnya kecuali dengan kekuatan".

1 M. Hasbi Amiruddin, Ulama Dayah, Pengawal Agama Masyarakat Aceh (Lhokseumawe: Nadiya Foundation, 2003), hal. 33. 
Makna yang dapat diambil dari firman Allah di atas, bahwa al-Qur'an sejak empat belas abad yang silam telah memberikan isyarat secara ilmiah kepada bangsa jin dan manusia. Isyarat tersebut menunjukkan bahwa golongan jin dan manusia telah dipersilakan oleh Allah untuk menjelajah sampai keluar angkasa asalkan mereka mempunyai kemampuan dan kekuatan (sulthan) untuk melakukannya. Kekuatan yang dimaksud di sini menurut sebagian ulama adalah ilmu pengetahuan atau sain dan teknologi, dan hal ini telah terbukti di era modern sekarang ini dengan di temukan alat komunikasi dan transportasi.

Ayat di atas merupakan dorongan bagi manusia untuk menggali ilmu pengetahuan dan teknologi agar mereka mampu menjelajahi dunia hingga keluar angkasa. Oleh karena itu, santri dayah sebagai manusia yang diberikan potensi oleh Allah untuk berpikir dan menggali berbagai pengetahuan tentu perlu melanjutkan pendidikan ke tempat yang dapat membekali mereka dengan berbagai disiplin ilmu pengetahuan agar mereka mempunyai kemampuan dan kekuatan untuk melakukan terobosan-terobosan baru dalam bidang ilmu pengetahuan dan teknologi. Untuk mewujudkan hal ini santri dayah perlu membuka cakrawala berpikir yang lebih kritis dengan melanjutkan pendidikan ke perguruan tinggi sebagai wadah yang banyak membekali mereka dengan berbagai bidang pengetahuan terutama perkembangan ilmu pengetahuan dan teknologi yang sesuai dengan tuntutan kemajuan zaman. Hal ini akan menjadikan santri dayah sebagai cendekiawan muslim yang tidak hanya ahli dalam bidang agama, tetapi juga mampu mengaitkan konsep Islam klasik dengan realitas modern. Karena itu, proses transmisi ilmu pengetahuan harus pula dibarengi dengan proses tranformasi nilai-nilai modern yang islami dan sesuai tuntunan zaman.

Apabila dilakukan kajian mendalam tentang kenyataan yang terjadi bahwa santri dayah yang belum menempuh pendidikan di perguruan tinggi, sering diasumsikan sebagai kaum yang menutup diri dan cenderung apatis terhadap kemajuan ilmu pengetahuan dan teknologi sehingga menyebabkan mereka tidak mampu bersaing secara global karena tidak mempunyai kompetensi yang cukup dalam bidang ilmu pengetahuan dan penggunaan teknologi canggih. Oleh karena itu, santri dayah yang telah dibelaki dengan pengetahuan agama Islam tentu sangat perlu melanjutkan pendidikan ke perguruan tinggi agar mereka tidak diasumsikan sebagai kaum yang ketinggalan zaman dan apatis terhadap kemajuan ilmu pengetahuan dan teknologi. ${ }^{2}$

Namun demikian, apabila santri dayah tidak mempunyai skill dalam menggunakan teknologi canggih, maka akan menyebabkan terbatasnya pergerakan mereka untuk mengakses dunia luar dayah, sehingga akses untuk memperoleh penunjang kehidupan pun menjadi terhambat. Hal ini sebagaimana diungkapkan oleh Nurcholis Madjid bahwa keahlian yang dikembangkan di dayah hanya berkisar pada penguasaan nahwu-sharaf, fiqh, aqa'id, tasawuf, hadis, bahasa Arab dan lain-lain. ${ }^{3}$ Mengacu pada pendapat Nurcholis Madjid ini, Yasmadi dalam bukunya Modernisasi Pesantren menyimpulkan bahwa salah satu kurangnya kemampuan skill ini karena keterbatasan kurikulum yang dimiliki oleh Pesantren tradisional. ${ }^{4}$

Sejumlah kekurangan yang dimiliki oleh dayah membuat dayah kurang diminati oleh para santri yang telah menetap, sehingga para santri tidak bertahan lama untuk

\footnotetext{
${ }^{2}$ Muslim Thahiry, dkk, Wacana Pemikiran Santri...., hal. 167

3 Nurcholis Madjid, Bilik-bilik Pesantren, Sebuah Potret Perjalanan, cet ke-I, (Jakarta: Paramadina, 1997), hal. 7-13.

4 Yasmadi, Modernisasi Pesantren, Kritik Nurcholis Madjid Terhadap Pendidikan Islam Tradisional, cet ke-II (Jakarta: Quantum Teaching, 2005), hal. 78-80.
} 
menetap di dayah, lebih memilih pendidikan di tempat yang lain seperti melanjutkan ke perguruan tinggi.

Ketika penulis ke Bireuen, penulis berkesempatan mengunjungi dayah yang ada di Bireuen dan penulis melakukan wawancara dengan pimpinan dan para teungku yang ada di dayah tersebut. Dalam wawancara ada beberapa poin yang penulis ajukan, yang pertama jumlah santri yang sedikit dan yang kedua jumlah tingkat santri dalam melanjutkan pendidikan ke perguruan tinggi.

Oleh sebab itu para santri pada umumnya bertahan menimba ilmu sampai menyelesaikan pendidikan tingkat menegah atas. Setelah itu, mereka keluar dari dayah dengan alasan akan melanjutkan pendidikan ke perguruan tinggi sehingga jumlah santri di dayah relatif stabil.

Kemunculan sejumlah lembaga pendidikan formal yang menerapkan proses belajar mengajar secara penuh, sebenarnya meniru para santri dayah untuk melanjutkan perguruan tinggi di sejumlah kampus yang ada di Aceh. Selain itu lowongan kerja yang disediakan pemerintah hanya berfokus pada lulusan perguruan tinggi menjadi suatu alasan bagi santri dayah untuk melanjutkan pendidikan agar mereka tertampung di pemerintahan atau di perusahaan-perusahaan swasta.

Berdasarkan pengamatan dan catatan dari peneliti bahwa tingkat motivasi santri dayah salafiyah Bireuen terhadap perguruan tinggi semakin meningkat. Hal ini terjadi karena persaingan yang menuntut para santri dayah untuk melanjutkan pendidikan di perguruan tinggi.

\section{Jenis dan Metode Penelitian}

Metode kajian yang penulis gunakan dalam penelitian ini adalah bersifat studi lapangan (field research) dengan menggunakan penelitian kualitatif. ${ }^{5}$ Karena riset ini bersifat deskriptif, data digambarkan dalam keadaan sewajarnya atau sebagaimana adanya ${ }^{6}$ dan data yang dikumpulkan berbentuk kata atau gambar dari pada angka. ${ }^{7}$

Dalam penelitian ini penulis menggunakan model analisis deskriptif kualitatif, karena masalah yang diteliti adalah suatu realita yang terjadi dalam kehidupan dan dijelaskan seperti apa adanya. Sebagaimana Nawawi menjelaskan bahwa konsep metode deskriptif ialah "Metode yang memusatkan perhatian pada masalah-masalah yang ada pada saat penelitian dilakukan, atau masalah-masalah bersifat aktual dengan menggambarkan fakta-fakta tentang masalah-masalah yang diselidiki sebagaimana adanya." 8 Maka dalam penelitian ini, peneliti akan menggambarkan sesuatu yang sedang berlangsung (aktual) secara sistematis dan efektif pada saat penelitian, memeriksa sebab-sebab dan gejala tertentu terhadap partispasi atau motivasi santriwati dayah salafiyah Bireuen dalam melanjutkan pendidikan ke perguruan tinggi, semuanya dijelaskan secara objektif serta dianalisis.

Selain itu, dalam bukunya Nasution menjelaskan bahwa penelitian kualitatif pada hakikatnya mengawasi orang dalam lingkungannya, berintegrasi dengan mereka,

${ }^{5}$ Metodologi kualitatif adalah prosedur penelitian yang menghasilkan data deskriptif berupa kata-kata yang tertulis atau lisan dari orang-orang dan perilaku yang dapat diamati. Lihat: Moleong, Metodologi Penelitian Kualitatif, (Bandung: Rosdakarya,1997), hal. 3.

${ }^{6}$ Hadari Nawawi dan Mimi Martini, Penelitian Terapan, (Yogyakarta: Gajah Mada University Press, 1996), hal. 174-175.

7 Imron Arifin, Penelitian Kualitatif dalam Ilmu-Ilmu Sosial dan Keagamaan, (Malang: Kalimasahada Press, 1996), hal. 49.

${ }^{8}$ Nawawi H. Hadan, Metodelogi Penelitian Bidang Sosial, (Yogyakarta: Gajah Mada University Press, 1991), hal 36. 
berusaha memahami bahasa dan tafsirannya tentang dunia sekitarnya. ${ }^{9}$ Informasi atau data penelitian ini berupa pemahaman terhadap motivasi santri dayah salafi dapat diperoleh dari data yang berupa lisan, interaksi dengan responden, maupun berupa tulisan yang diperoleh melalui data dan catatan yang resmi lainnya. Langkah seperti ini dilaksanakan oleh peneliti bertujuan untuk menemukan peluang-peluang berdasarkan asumsi dan teori yang telah dirumuskan sebelumnya oleh para ahli penelitian sehingga dimungkinkan si peneliti untuk mendapatkan data akurat tentang motivasi santri dayah salafiyah dalam melanjutkan pendidikan ke perguruan tinggi.

1. Sumber Data

Dalam melakukan penelitian ini, peneliti menggunakan dua sumber data ${ }^{10}$. Pertama, sumber data yang berasal dari santri ataupun teungku dayah MUDI Mesra Samalanga dan Dayah Muslimat. Kedua, sumber yang berupa dokumen-dokumen termasuk buku-buku primer ataupun sekunder, majalah, diktat dan sumber data lain yang dikategorikan dalam dokumen-dokumen. Data primer, adalah data yang sangat pokok dalam pembahasan sebuah permasalahan dalam penelitian. Menurut Husein Umar, "data primer adalah data yang diperoleh dari sumber perorangan seperti wawancara". ${ }^{11}$ Adapun yang menjadi sumber data primer dalam penelitian ini adalah wawancara yang dilakukan dengan para santriwati yang menjadi sampel. Wawancara tersebut berisi pertanyaan-pertanyaan tentang hal-hal yang berkaitan dengan motivasi santriwati dayah salafiyah Bireuen dalam melanjutkan pendidikan ke Perguruan tingggi dan bertujuan untuk memperoleh informasi yang akurat mengenai pendapat responden.

Selain itu, data primer juga diperoleh melalui dokumentasi di dayah MUDI Mesra Samalanga dan Dayah Muslimat. Sedangkan data sekunder adalah data pendukung yang digunakan peneliti dalam penyusunan penelitian ini. Data sekunder diperoleh dengan bertujuan untuk mengumpulkan informasi sebanyak-banyaknya mengenai suatu objek kajian penelitian. Wawancara dilakukan langsung dengan responden mengenai berbagai hal yang berkaitan dengan motivasi santri dayah salafiyah Bireuen dalm melanjutkan pendidikan ke perguruan tinggi. Selain itu juga, diperoleh melalui library research (penelitian pustaka), yaitu pengumpulan data dengan cara menelaah buku-buku, majalah, situs website (internet) dan referensi-referensi yang relevan dengan penelitian ini.

2. Teknik Pengumpulan Data

Dalam pengumpulan data dilakukan dengan cara wawancara, dan dokumentasi. Dalam wawancara dilengkapi dengan daftar pertanyaan dan alat perekam data yang berupa tape recorder dan alat tulis lainnya. Berikut penjelasannya:

a. Wawancara

Wawancara adalah proses memperoleh keterangan untuk tujuan penelitian dengan cara tanya jawab, sambil bertatap muka antara si penanya dengan si penjawab dengan mengunakan interview guide (pedoman wawancara), hubungan antara peneliti

${ }^{9}$ S. Nasution, Metode Penelitian Naturalistik Kualitatif, (Bandung: Tarsito, 1988), hal. 5.

${ }^{10}$ Data dari bahasa Latin datum (tunggal), pemberian, karunia, sajian, data (jamak), hadiahhadiah, sajian-sajian. 1. Informasi aktual (pengukuran atau statistik) yang digunakan sebagai dasar untuk penelaahan, diskusi atau pehitungan. 2. Kenyataan-kenyataan murni yang belum ditafsirkan, diubah atau dimanipulasikan, tetapi telah tersusun dalam sistematika tertentu. Lihat Komaruddin dkk, Kamus Istilah Karya Ilmiah, Cet. 1, (Jakarta: Bumi Aksara, 2000), hal. 43.

${ }^{11}$ Husein Umar, Metodologi Penelitian Untuk Skripsi, Thesis, dan Bisnis, (Jakarta: Grafindo Persada, 2008), hal. 12. 
dengan pemberi informasi. ${ }^{12}$ Bukan antara atasan dengan bawahan, melainkan peneliti datang meminta kesediaannya dalam memberi informasi. Adapun yang menjadi si penjawab dalam penelitian ini adalah langsung dengan para santriwati dan dewan guru di dayah tempat penulis melakukan penelitian.

\section{b. Dokumentansi}

Dokumentasi yaitu pengumpulan data yang diperoleh melalui sumber tertulis, dengan kata lain mencari data mengenai hal-hal atau variabel yang berupa catatan, transkrip, buku, surat kabar, majalah, prasasti, notulen rapat dan sebagainya. ${ }^{13}$ Dokumentasi ini dilakukan untuk memperoleh data tambahan dengan cara menelaah sejumlah data tertulis yang berkaitan dengan penelitian ini. Dalam penelitian ini dokumen yang ditelaah adalah sekitar sistem, pola pengajaran dan penggunaan media elektronik dalam menunjang proses administrasi dan PBM (proses belajar mengajar) di dayah MUDI Mesra Samalanga dan Dayah Muslimat.

\section{Lokasi Penelitian}

Adapun yang menjadi lokasi ataupun menjadi subjek penelitian hanyalah dua dayah yaitu dayah MUDI Mesra Samalanga dan Dayah Muslimat. Pengambilan lokasi penelitian di dua dayah tersebut karena dari hasil pengamatan peneliti terdapat fenomena seperti yang telah digambarkan pada latar belakang masalah sehingga lebih akurat dalam memperoleh data.

Penulis meneliti di dua dayah tersebut tentang motivasi santriwati dayah salafiyah Bireuen dalam melanjutkan pendidikan ke perguruan tinggi. Peneliti tertarik dengan dua dayah tersebut, terutama berbeda tipe berdasarkan keputusan Badan Dayah Provinsi Aceh. Adapun dayah yang tipe A adalah dayah MUDI Mesra Samalanga, tipe B dayah Dayah Muslimat.

\section{Populasi dan Sampel}

Populasi adalah "keseluruhan objek penelitian" sedangkan sampel adalah "sebagian atau wakil populasi yang diteliti". ${ }^{15}$ Penarikan sampel dalam penelitian ini merupakan sampel yang bertujuan (purposive sampling). Artinya, sampel yang ditarik atau diambil berdasarkan tujuan penyelidikan. ${ }^{16}$ Sementara jumlah populasi yang seharusnya dalam penelitian ini adalah seluruh dayah salafiyah di Kabupaten Bireuen berjumlah 47 dayah. Berhubung populasi terlalu luas dan terlalu banyak sehingga tidak memungkinkan untuk diteliti secara keseluruhan, maka penulis memilih dua dayah untuk dijadikan sampel yang dianggap dapat mewakili secara keseluruhan.

Adapun sampel yang dipilih adalah dua dayah salafiyah yang ada di Kabupaten Bireuen yaitu dayah MUDI Mesra Samalanga dan Dayah Muslimat. Kedua dayah ini

\footnotetext{
${ }^{12}$ Suharsimi Arikunto, Prosedur Penelitian Suatu Pendekatan Praktik, (Jakarta: Rineka Cipta, 2002), hal. 108.

${ }^{13}$ Suharsimi Arikunto, Prosedur Penelitian Suatu Pendekatan Praktek, Cet.13 (Jakarta: Rineka Cipta, 2006), hal. 231.

${ }^{14}$ Suharsimi Arikunto, Prosedur Penelitian Suatu Pendekatan Praktek, (Jakarta: Rineka Cipta, 2002), hal. 108.

${ }^{15}$ Suharsimi Arikunto, Prosedur Penelitian ..., hal. 109.

16 Christine Daymon dan Immy Holloway, Metode-metode Riset Kulaitatif dalam Public Relations and Marketing Communications, Terj. Cahya Wiratama, Cet. I, (Yogyakarta: Bentang, 2008), hal. 243.
} 
dipilih karena, memiliki perbedaan dari segi tipe, jumlah santri, Sumber data diperoleh dari santri ataupun teungku dayah. Karena jumlah anggota populasi yang terlalu besar, maka penulis mengambil sampel dengan cara seperti telah di sebutkan di atas yaitu " purposive sampling" atau sampel bertujuan. Jumlah anggota sampel tidak ditentukan jumlahnya, tetapi tergantung pada pemenuhan terhadap data yang dibutuhkan. Jika sampel yang dibutuhkan untuk menjawab pertanyaan penelitian yang telah dikemukakan pada rumusan masalah dalam penelitian ini sudah terpenuhi maka anggota sampel dipandang sudah cukup dan memadai.

\section{Hasil Penelitian dan Pembahasan}

\section{Motivasi Santri}

Motivasi berarti kecenderungan yang timbul pada diri seseorang secara sadar atau tidak sadar melakukan sesuatu untuk mencapai tujuan yang dikehendaki, dalam hal ini penulis ingin memaparkan hasil penelitian yang sudah penulis lakukan tentang motivasi santri dayah salafiyah untuk melanjutkan pendidikan keperguruan tinggi. Berdasarkan hasil wawancara peneliti dengan para santri tentang motivasi mereka melanjutkan pendidikan ke perguruan tinggi sangatlah bermacam-macam mulai dari keinginan diri sendiri dan juga karena adanya dukungan dari teungku dan dorongan dari orang tua. Seperti hasil wawancara dengan salah satu santriwati yaitu Tengku Maisura, yang mengungkapkan bahwa:

"Keinginan untuk melanjutkan pendidikan ke perguruan tinggi adalah keinginan saya sendiri dan tidak ada paksaan dari siapapun. Keinginan ini sudah saya niatkan semenjak saya pertama masuk pesantren dimana nanti ketika saya sudah mendapatkan ijazah tingkat 'Aliyah di pesantren saya akan melanjutkan pendidikan ke perguruan tinggi untuk menambah wawasan keilmuan saya terutama dalam bidang agama Islam." 17

Berdasarkan hasil wawancara di atas, dapat dipahami bahwa motivasi santri melanjutkan kuliah merupakan motivasi yang lahir dari dirinya sendiri dan tidak ada paksaan dari orang tua maupun teungku dayah. Dengan demikian dapat dipahami bahwa ada santri dayah yang telah menyadari tentang pentingnya melanjutkan pendidikan ke perguruan tinggi untuk menambah ilmu pengetahuan dan mencari pengalaman yang tidak didapatkan di dayah. Hal ini sebagaimana diungkapkan oleh teungku Raudhah.

"Saya ingin lebih memperkaya pengalaman, pengetahuan, dan saya ingin faham tentang penelitian, moga-moga kelak dakwah yang saya sampaikan bisa sesuai dengan keadaan sosial dan mudah dicerna di semua kalangan"18

Berdasarkan ungkapan di atas, dapat dipahami bahwa motivasi santriwati melanjutkan pendidikan ke perguruan tinggi karena keinginan diri sendiri yang timbul dari kesadaran akan pentingnya ilmu pengetahuan dan pengalaman dalam kehidupan bermasyarakat dan juga untuk menyampaikan dakwah yang lebih menyentuh kepada nilai-nilai sosial yang sangat penting dipahami oleh seorang pendakwah. Motivasi santriwati untuk melanjutkan pendidikan ke perguruan tinggi juga diungkapkan oleh teungku Dewi.

${ }^{17}$ Hasil Wawancara dengan Tgk Maisura santriwati Dayah MUDI Mesra Samalanga, 10 Juli 2019.

${ }^{18}$ Hasil Wawancara dengan Tgk Raudhah Santriwati Dayah Muslimat, 11 Juli 2019. 
"Sebagai seorang santriwati yang telah lama belajar di dayah dan telah banyak mendapatkan ilmu di dayah, saya berkeinginan untuk melanjutkan pendidikan ke perguruan tinggi. Keinginan saya melanjutkan kuliah bukan karena dorongan dari orang tua dan juga pimpinan dayah, tetapi keinginan saya sendiri untuk menambahkan ilmu pengetahuan dan mencari wawasan baru di kampus yang belum pernah saya dapatkan di dayah selama saya belajar."19

Berdasarkan hasil wawancara di atas, dapat dipahami bahwa santriwati tersebut melanjutkan pendidikan ke perguran tinggi karena keinginan dia sendiri dan bukan karena dorongan orang tua dan juga pimpinan dayah. Dengan demikian dapat dipahami bahwa jenis motivasi intrinsik merupakan salah satu motivasi santri melanjutkan pendidikan ke perguruan tinggi. Berdasarkan hasil wawancara penulis dengan santriwati dayah dapat diketahui bahwa jenis motivasi instrinsik ini juga ada pada teungku Salwa yang mengungkapkan bahwa:

"Saya melanjutkan kuliah keperguruan tinggi tidak mendapatkan dorongan dari orang tua dan keluarga saya, bahkan mereka tidak mendukung saya untuk kuliah, karena mereka sangat menginginkan saya menjadi teungku saja tanpa harus mendapatkan gelar di perguruan tinggi. Namun karena keinginan yang kuat saya tetap melanjutkan perguruan tinggi karena saya merasa sangat membutuhkan ilmu dan pemikiran-pemikiran baru yang ada di kampus yang akan mendidik saya lebih berwawasan dan luas dalam berpikir" 20

Berdasarkan pernyataan di atas, dapat dipahami bahwa motivasi instrinsik merupakan motivasi utama bagi sebagian santriwati dayah melanjutkan pendidikan ke perguruan tinggi. Motivasi dari sendiri ini juga diungkapkan oleh teungku Nurul bahwa:

"Saya pertama masuk pesantren tidak terpikir untuk kuliah, tetapi setelah beberapa tahun menimba ilmu dipesantren dan telah banyak membaca beberapa kitab-kitab yang ada di pesantren saya belum cukup puas dengan apa yang telah saya dapatkan. Akhirnya berkeinginan untuk mencari ilmu diperguruan tinggi Islam untuk mencoba memahami sisi perbedaan pemikiran dayah dengan pemikiran dosen di perguruan tinggi" 21

Berdasarkan pernyataan di atas, dapat dipahami bahwa motivasi santriwati juga lahir dari keinginannya untuk memahami sisi perbedaan pemikiran teungku dayah dengan pemikiran dosen di perguruan tinggi. Hal ini tentu sesuai dengan kejadian yang sering terjadi akhir-akhir ini bahwa adanya perbedaan pemahaman antara teungku dayah dengan dosen diperguruan tinggi terutama masalah khilafiyah dalam bidang fiqih. Dengan demikian dapat dipahami bahwa motivasi santri melanjutkan perguruan tinggi seperti ini adalah jenis motivasi instrinsik yang lahir dari dirinya sendiri.

Seseorang atau suatu organisme yang berbuat atau melakukan sesuatu, sedikit banyaknya ada kebutuhan di dalam dirinya atau ada sesuatu yang ingin dicapai. Dalam hal ini untuk memenuhi kebutuhan tersebut diperlukan motivasi atau pendorong. Jika seseorang mendapat motivasi yang tepat untuk mencapai tujuan yang diinginkan, maka lepaslah tenaga yang luar biasa, sehingga tercapai hasil-hasil yang tidak terduga.

\footnotetext{
${ }^{19}$ Hasil Wawancara dengan Tgk Dewi santri Dayah MUDI Mesra Samalanga, 11 Juli 2019.

${ }^{20}$ Hasil Wawancara dengan Tgk Salwa santri Dayah Muslimat, 12 Juli 2019

${ }^{21}$ Hasil Wawancara dengan Tgk Nurul santri Dayah MUDI Mesra Samalanga, 12 Juli 2019
} 
Apabila dikaitkan dengan santri, maka motivasi merupakan suatu hal yang sangat penting bagi santri agar tujuannya dapat dicapai yang dalam hal ini adalah melanjutkan pendidikan ke perguran tinggi. Namun demikian, motivasi instrinsik santri melanjutkan pendidikan ke perguruan tinggi juga didorong oleh persepsi mereka sendiri terhadap kebutuhan pendidikan yang sesuai dengan tuntutan zaman. Hal ini dapat diketahui dari hasil wawancara penulis dengan teungku Waraqah yang mengungkapkan bahwa:

"Saya termotivasi untuk melanjutkan pendidikan ke perguruan tinggi, karena zaman sekarang ini semakin maju dan berkembang sehingga saya termotivasi melanjutkan ke perguruan tinggi dan untuk melihat perkembangan pendidikan yang ada di kampus"22

Berdasarkan pendapat tersebut dapat dipahami bahwa salah satu motivasi santriwati melanjutkan pendidikan ke perguruan tinggi adalah karena tututan zaman yang terus maju dan berkembang sehingga santri dayah merasa penting dan perlu untuk menimba ilmu pengetahuan di perguruan tinggi untuk menambah khazanah keilmuan dan memperkaya pengalaman sehingga tidak terjadi kejumudan dalam berpikir. Selain itu, santri dayah salafiyah juga banyak melihat dan mendengar pengalaman-pengalaman kawan-kawan mereka yang telah melanjutkan studi ke perguruan tinggi tentang tata cara berorganisasi dan melakukan kegiatan-kegiatan sosial kemasyarakatan.

\section{Persepsi Tengku dan Santri Dayah}

Sebelum memberikan penjelasan tentang persepsi teungku dan santri dayah terhadap perguruan tinggi terlebih dahulu penulis menjelaskan tentang pengertian persepsi itu sendiri. Persepsi adalah suatu proses yang dilakukan seseorang untuk memperoleh gambaran mengenai sesuatu melalui tahap pemilihan, pengelolaan, dan pengertian dari informasi mengenai sesuatu tersebut. Tindakan seseorang yang sesuatu hal banyak dipengaruhi oleh hal tersebut.

Mulyana mendefinisikan persepsi sebagai suatu proses internal yang memungkinkan kita untuk memilih, mengorganisasikan serta menafsirkan rangsangan dari lingkungan kita dan dari proses tersebut dapat mempengaruhi perilaku kita nantinya. ${ }^{23}$

Persepsi juga merupakan proses dimana individu memilih, mengorganisasi dan menginterprestasi apa yang dibayangkan tentang dunia di sekelilingnya. Jadi dengan mempersepsi setiap individu memandang dunia berkaitan dengan apa yang dibutuhkan, apa yang dinilai, apakah sesuai dengan keyakinan budayanya. Semua kebutuhan yang ingin dipenuhi ini membuat persepsi individu menjalani suatu proses personal yang rumit, karena apa yang dia persepsikan itu sangat tergantung dari sejauh mana beragam faktor pembentuk persepsi, antara lain masa lalu individu. Pengalaman masa lalu tersebut rupanya telah membekas lalu membentuknya untuk memandang sesuatu, memandang seseorang atau suatu peristiwa dengan cara-cara tertentu. Karena itu, setiap individu dapat melihat suatu objek yang sama namun dengan cara yang berbeda.

Persepsi setiap orang juga berbeda-beda sesuai dengan makna yang dia berikan kepada"sesuatu", kepada seseorang atau kepada peristiwa. Di sini penting untuk dicatat bahwa semua manusia tidak dapat mengelak persepsi yang mempengaruhi komunikasi. Jika seorang pengirim membagi informasi dengan maksud tertentu kepada penerima,

\footnotetext{
${ }^{22}$ Hasil Wawancara dengan Tgk Warqah santri Dayah MUDI Mesra Samalanga, 12 Juli 2019

${ }^{23}$ Mulyana, Ilmu Komunikasi Suatu Pengantar, (Jakarta: Rineka Cipta, 2001), hal. 167.
} 
maka suka atau tidak suka penerima akan menerima informasi yang dimaksud pengirim. ${ }^{24}$

Persepsi pada hakekatnya adalah proses kognitif yang dialami oleh setiap orang di dalam memahami informasi tentang lingkungannya, lewat penglihatan, pendengaran, penghayatan, perasaan, dan penciuman. Persepsi adalah suatu proses kognitif yang kompleks dan yang menghasilkan suatu gambar unik tentang kenyataan yang barangkali sangat berbeda dari kenyataannya. Dengan demikian, dapat disimpulkan bahwa persepsi sangat bersifat pribadi dan usaha sungguh-sungguh memahami persepsi orang merupakan bagian penting dari studi perilaku organisasi. Dalam kehidupan berorganisasi, sering sekali kita dihadapkan pada perbedaan interprestasi yang menyebabkan perbedaan pilihan tindakan dan perilaku terhadap suatu obyek yang sama.

Persepsi adalah proses seseorang mengetahui beberapa hal melalui panca indra. ${ }^{25}$ Maksud persepsi di sini adalah proses yang menyangkut masuknya pesan atau informasi ke dalam otak manusia melalui penginderaan yang mempergunakan apa yang ada dalam diri individu baik itu berupa fikiran, perasaan, pengalaman-pengalaman individu yang ikut aktif berpengaruh dalam proses persepsi itu sendiri. Akan tetapi, setiap persepsi orang itu berbeda-beda cara memberikan tanggapan karena apa yang dilihatnya belum tentu sama dengan fakta yang sebenarnya.

Dari pengertian persepsi di atas dapat dijelaskan bahwa persepsi teungku dayah tentang perguruan tinggi atau bagaimana teungku dayah menilai pendidikan di perguruan tinggi tentu dapat memunculkan bermacam-macam interprestasi ada yang bersifat positif dan negatif. Lahirnya suatu persepsi teungku dayah yang bersifat positif dan negatif terhadap perguruan tinggi tidak terlepas dari pola pikirnya masing-masing. Dimana ada di antara teungku dayah yang pola pikirnya sudah luas sangat mendukung para santrinya untuk kuliah, karena menganggap kuliah itu dapat menambah wawasan dan memperkaya pengetahuan santri sesuai dengan tuntutan zaman. Namun ada juga di antara teungku dayah yang masih sempit dalam berpikir, sehingga melarang santrinya untuk kuliah karena menganggap kuliah dapat merusak aqidah santri yang telah bertahun-tahun belajar agama di dayah. Hal ini sebagaimana wawancara penulis dengan teungku Multia tentang persepsi beliau terhadap perguran tinggi sebagai berikut:

"Pendapat saya pribadi bahwa menimba ilmu pengetahuan di kampus itu penting, karena pendidikan di kampus sudah disesuaikan dengan tuntutan zaman, sehingga dapat membuka pola pikir yang luas dan mampu memperkaya pengalaman yang sangat bermanfaat bagi kemajuan bangsa dan agama" 26

Berdasarkan pendapat di atas, dapat dipahami bahwa teungku dayah juga mendukung keberadaan perguruan tinggi sebagai lembaga pendidikan formal yang sangat berperan dalam mencerdaskan kehidupan bangsa dan membentuk budi pekerti yang luhur. Oleh karena demikian, dapat dikatakan bahwa tidak semua teungku dayah anti kepada kampus dan bahkan ada dayah yang telah memasukkan program kuliah di dayah, agar memudahkan para santri dapat melanjutkan pendidikan ke perguruan tinggi. Namun demikian, ada juga teungku dayah yang menganggap tidak penting untuk melanjutkan pendidikan ke perguruan tinggi, karena mereka berasumsi bahwa banyak mahasiswa di kampus yang rusak aqidah karena mudah terpengaruh dengan aliran-

\footnotetext{
${ }^{24}$ Alo Liliweri, Komunikasi Serba Ada Serba Makna, (Jakarta: Kencana, 2011), hal. 153.

${ }^{25}$ Dedikbud, Kamus Besar Bahasa Indonesia, hal. 759.

${ }^{26}$ Hasil Wawancara dengan Tgk Multia Dayah MUDI Mesra Samalanga, 12 Juli 2019
} 
aliran yang menyimpang dari ajaran Islam. Informasi ini mereka dapatkan dari media cetak maupun elektronik bahwa sebagian mahasiswa terjerumus dalam aliran sesat. hal ini seperti yang dikatakan oleh Teungku Fatimah sebagai berikut:

"Menurut saya kampus itu bagus, akan tetapi akhir-akhir ini, banyak informasi yang saya baca di media bahwa ada mahasiswa yang telah terjerumus ke dalam aliran sesat, sehingga saya merasa khawatir akan rusaknya aqidah santri bila kuliah di perguruan tinggi" 27

Adanya kekhawatiran sebagian teungku dayah tersebut merupakan suatu kekhawatiran yang wajar, karena mereka sangat tidak menginginkan santri yang telah lama belajar di dayah akan terpengaruh dengan aliran-aliran yang menurut mereka tidak sesuai dengan ajaran Islam sebagaimana yang mereka pahami. Apalagi akhir-akhir ini proses penerimaan mahasiswa di perguruan tinggi baik perguruan tinggi Islam maupun umum sangat kurang mengutamakan kemampuan calon mahasiswa memahami agama terutama baca Al-Qur'an. Hal ini sebagaimana ungkapan Rektor Unsyiah di serambi Indonesia pada tanggal 28 Juli 2015 yang bahwa $82 \%$ mahasiswa yang telah diterima diperguruan tinggi tidak mampu membaca Al-Qur'an.

Persepsi lain teungku dayah terhadap kampus bahwa kampus sebagai lembaga pendidikan formal tentu sangat dibutuhkan oleh masyarakat, karena kampus sangat berperan penting dalam mendidik generasi bangsa dalam melahirkan generasi intelaktual yang mampu berpikir kritis untuk memajukan bangsa sesuai dengan perkembangan zaman terutama dalam bidang ilmu pengetahuan, teknologi dan agama. Akan tetapi teungku dayah sangat merasa khawatir dengan pergaulan muda-mudi yang kurang terkontrol di kampus. Hal ini sebagaimana ungkapan teungku Hasnaii sebagai berikut:

"Menurut saya keberadaan kampus di tengah-tengah masyarakat itu sangat penting, karena kampus memiliki peran penting dalam memajukan bangsa baik dalam bidang teknologi maupun ilmu pengetahuan dan agama. Namun saya sangat khawatir dengan pergaulan muda-mudi di kampus yang kurang terkontrol dan seharusnya pihak kampus tidak membiarkan masalah ini’,28

Berdasarkan pendapat di atas, dapat dipahami bahwa teungku dayah juga mengakui kelebihan kampus dalam bidang pengembangan ilmu pengetahuan dan teknologi, akan tetapi sangat mengkhawatirkan pergaulan sebagian mahasiswa di kampus yang dapat menciderai ajaran Islam. Di samping itu, ada juga teungku dayah yang menilai bahwa kampus kurang membekali ilmu agama kepada mahasiswa, terutama perguruan tinggi umum. Padahal menurut teungku dayah kampus sebagai lembaga pendidikan formal juga harus mengutamakan pendidikan keagamaan sebagai pondasi moral dan etika saat berkarir atau bekerja maupun ketika terjun di masyarakat. Sebagaimana yang diungkapkan oleh teungku Hindun sebagai berikut:

"Menurut saya perguruan tinggi sebagai lembaga pendidikan yang memiliki peran penting dalam mendidik generasi bangsa, sangat perlu mengutamakan pendidikan keagamaan terutama pada perguruan tinggi umum yang masih

\footnotetext{
${ }^{27}$ Hasil Wawancara dengan Tgk. Fatimah Dayah MUDI Mesra Samalanga, 12 Juli 2019

${ }^{28}$ Hasil Wawancara dengan Tgk. Hasnaini Dayah Muslimat, 13 Juli 2019
} 
kurang pembinaan keagaaman bagi mahasiswa. Supaya mereka dapat menjadi intelektual yang mampu menjalankan Islam secara baik dan benar" ${ }^{29}$

Berdasakan pendapat di atas, dapat dipahami bahwa perguruan tinggi adalah pranata yang muncul dan berkembang dalam kehidupan masyarakat karena kehadirannya dirasakan penting oleh mereka, dalam upaya memenuhi kebutuhan pendidikan tinggi bagi warganya. Selanjutnya yang menjadi pengertian dari variabel persepsi teungku dayah tentang perguruan tinggi di atas adalah bagaimana para teungku dayah menilai perguruan tinggi terkait dengan kualitas dari out put yang dihasilkan.

Perguruan tinggi dalam pandangan teungku dayah adalah sesuatu yang sangat penting untuk membina generasi penerus bangsa dalam menghadapi tantangan kemajuan zaman. Hal ini sebagaimana hasil wawancara penulis dengan teungku Mukhdasir bahwa:

"Saya pribadi berpendapat bahwa kampus memiliki peran penting dalam mendidik generasi bangsa yang harus berwawasan luas dalam menghadapi tantangan kemajuan zaman. Dimana kalau santri tidak melanjutkan pendidikan ke perguruan tinggi, maka mereka tidak akan mampu menyesuaikan diri dengan perkembangan zaman",30

Berdasarkan pendapat di atas, dapat dipahami bahwa sudah ada suatu kesadaran tersendiri bagi teungku dayah tentang pentingnya melanjutkan pendidikan ke perguruan tinggi agar santri mampu bersaing dalam mengikuti perkembangan zaman yang menuntut manusia agar memiliki wawasan yang luas dalam hidup berbangsa dan bernegara. Oleh karena itu ada sebagian teungku dayah bahkan menganjurkan serta mendorong para santrinya untuk melanjutkan pendidikan keperguruan tinggi. Hal ini sebagaimana hasil wawancara penulis dengan teungku Zuhdi yang mengungkapkan bahwa:

"Menurut saya sudah saatnya santri-santri dayah menimba ilmu diperguruan tinggi, karena disanalah mereka akan mendapatkan ilmu pengetahuan dan pengalaman yang sangat dibutuhkan oleh masyarakat. Karena itu, saya sendiri pernah menganjurkan dan mendorong santri untuk melanjutkan pendidikan ke perguruan tinggi" 31

Berdasarkan pendapat di atas dapat dipahami bahwa teungku dayah pada umumnya mendukung dan mendorong santriwati untuk melanjutkan pendidikan ke perguruan tinggi, karena dapat menambahkan wawasan keilmuan dan pengalaman bagi santri. Namun demikian ada juga sebagian teungku dayah yang berpandangan negatif terhadap perguruan tinggi. Pandangan negatif ini seperti yang diungkapkan oleh teungku Syahrul bahwa:

Menurut saya seorang santri yang telah lama belajar di dayah tidak perlu lagi untuk melanjutkan pendidikan ke perguruan tinggi, karena di dayah di ajarkan ilmu agama sedangkan di perguruan tinggi diajarkan ilmu dunia. Sedangkan ilmu mempelajari ilmu dunia dikhawatikan akan merusak ilmu agama santri

\footnotetext{
${ }^{29}$ Hasil Wawancara dengan Tgk. Hindun Dayah MUDI Mesra Samalanga, 12 Juli 2019

${ }^{30}$ Hasil Wawancara dengan Tgk. Mukhdasir Dayah MUDI Mesra Samalanga, 12 Juli 2019

${ }^{31}$ Hasil Wawancara dengan Tgk. Zuhdi Dayah MUDI Mesra Samalanga, 12 Juli 2019
} 
yang didapatkan di dayah. Apalagi selama ini saya sering mendengarkan banyaknya pemikiran dosen yang tidak sesuai dari pemikiran ulama dayah di Aceh. ${ }^{32}$

Berdasarkan pernyataan di atas, dapat dipahami bahwa ada sebagian teungku dayah yang masih berasumsi negatif terhadap perguruan tinggi, karena mereka masih membedakan ilmu agama dan ilmu dunia. Padahal yang penulis pahami semua ilmu bersumber dari Al-Qur'an dan tidak ada suatu larangan untuk dipelajari selama ilmu itu bermanfaat bagi manusia. Mengenai asumsi teungku dayah tentang adanya pemikiran dosen yang berbeda dengan pemikiran teungku dayah, hal ini ada benarnya teruma pada masalah khilafiyah, akan tetapi hal ini tentu tidak perlu untuk saling menyesatkan selama ada dalil yang kuat tentang masalah khilafiyah tersebut. Asumsi negatif lainnya teungku dayah terhadap perguruan tinggi dilihat dari sisi pergaulan mahasiswa yang sedang menimbah ilmu di kampus. Hal ini sebagaimana yang diungkapka oleh teungku M. Ali bahwa:

"Menurut saya menimba ilmu pengetahuan di perguruan tinggi memang suatu hal yang penting, tetapi saya ketika saya membaca media cetak dan melihat langsung kondisi pergaulan mahasiswa ketika saya ke banda Aceh, saya melihat perilaku mahasiswa yang kurang mencerminkan kaum intelektual yang diharapkan oleh bangsa ini khususnya Aceh yang kental dengan syari'at Islam"33

Berdasarkan pernyataan di atas, dapat dipahami bahwa teungku dayah mengakui tentang pentingya perguruan tinggi di tengah-tengah masyarakat. Akan tetapi yang disesalkan adalah perilaku sebagian mahasiswa yang cenderung tidak mencerminkan budaya Islami yang sesuai dengan syari'at Islam. Asusmsi ini ada benarnya karena akhir-akhir ini bisa dilihat bahwa pergaulan mahasiswa dengan lawan jenis cenderung tanpa batas dan sangat besar kemungkinan terjadinya perilaku dan hal-hal yang menyimpang dari ajaran Islam.

\section{Faktor Dukungan dan Hambatan}

1. Dukungan santriwati dalam melanjutkan pendidikan ke perguruan tinggi

Pendidikan adalah usaha sadar dan terencana untuk mewujudkan suasana belajar dan proses pembelajaran agar peserta didik secara aktif mengembangkan potensi dirinya untuk memiliki kekuatan spiritual keagamaan, pengendalian diri, kepribadian, kecerdasan, akhlak mulia, serta keterampilan yang diperlukan dirinya, masyarakat, bangsa dan negara. ${ }^{34} \mathrm{Hal}$ inilah yang menjadi tugas perguruan tinggi dalam mendidik generasi yang dapat bermanfaat bagi agama, nusa dan bangsa. Namun demikian, seseorang yang berkeinginan untuk melanjutkan pendidikan ke perguruan tinggi, tentu ada faktor pendukung dan penghambat yang yang dialaminya. Demikian juga dengan santri dayah yang ingin melanjutkan pendidikan ke perguruan tinggi tentu adanya faktor pendukung dan faktor penghambat yang dialami oleh santri tersebut. Salah satu fakor pendukung bagi santri untuk melanjutkan pendidikan ke perguruan tinggi adalah adanya dukungan dari pimpinan dayah sendiri. Hal ini sebagaimana ungkapan teungku Nurul sebagai berikut:

\footnotetext{
${ }^{32}$ Hasil Wawancara dengan Tgk. Syahrul Dayah Muslimat, 13 Juli 2019

${ }^{33}$ Hasil Wawancara dengan Tgk. M. Ali Dayah MUDI Mesra Samalanga, 12 Juli 2019

${ }^{34}$ Darmiwati, Implementasi Model Pembelajaran Perubahan Konseptual Untuk Meningkatkan Prestasi Belajar, (Banda Aceh: FKIP Unsyiah, 2006), hal. 1
} 
"Saya melanjutkan pendidikan ke perguruan tinggi karena mendapatkan dukungan dari pimpinan dayah dan bahkan beliau memberikan izin dan menganjurkan saya untuk kuliah",35

Selain itu, santriwati yang telah melanjutkan pendidikan keperguruan tinggi juga mendapatkan dukungan dari orang tua dan keluarga, karena tanpa dukungan dari keduanya santriwati akan sulit untuk dapat melanjutkan pendidikan ke perguruan tinggi. Hal ini sebagaimana diungkapan oleh teungku Dewi sebagai berikut:

"Saya bisa kuliah, karena mendapatkan dukungan dari orang tua dan keluarga baik dukungan secara moril maupun materil. Tanpa dukungan mereka, saya merasa sulit untuk bisa kuliah terutama menyangkut dengan dana dan biaya kuliah yang perlu dibantu oleh mereka" 36

Berdasarkan pendapat di atas, dapat dipahami bahwa faktor pendukung santri untuk melanjutkan kuliah adalah sebagai berikut:

a. Faktor dukungan untuk melanjutkan pendidikan ke perguruan tinggi yaitu dari pada Pimpinan dayah itu sendiri.

b. Orang tua

c. Keluarga

d. Bahkan dukungan dari segi materil.

2. Hambatan santri dalam melanjutkan pendidikan ke perguruan tinggi

Selain faktor pendukung yang telah penulis paparkan di atas, santri juga mengalami hambatan dalam melanjutkan pendidikan ke perguruan tinggi. Di antara faktor penghambat bagi santri dalam melanjutkan kuliah ke perguruan tinggi adalah kekurang ekonomi. Hal ini sebagaimana diungkapkan oleh teungku Maisura sebagai berikut:

"Bagi saya yang menjadi faktor penghambat saya dalam melanjutkan pendidikan ke perguruan tinggi adalah kurangnya ekonomi dari orang tua, sehingga menghambat kelancaran proses belajar yang saya tempuh diperguruan tinggi"37

Berdasarkan pendapat di atas, dapat dipahami bahwa di antara hambatan yang dialami oleh santri dayah dalam melanjutkan kuliah di perguruan tinggi adalah ekonomi yang kurang memadai. Demikian juga keadaan ekonomi keluarga yang kurang mencukupi menjadi salah satu penghambat dalam melanjutkan pendidikan. Faktor Ekonomi yang dimaksud adalah ketidakmampuan keluarga untuk membiayai segala proses yang dibutuhkan selama menempuh pendidikan dalam satu jenjang tertentu. Padahal, setiap orang tua tentu sangat mengharapkan anak yang cerdas dan sudah pasti harus menempuh jalur pendidikan terlebih dahulu. Maka keadaan sosial ekonomi orang tua sangat mempengaruhi tingkat pendidikan anak.

Selain ekonomi, faktor usia juga menjadi kendala bagi santri dayah untuk melanjutkan pendidikan ke perguruan tinggi. Di mana santri yang sudah lanjut usia

\footnotetext{
${ }^{35}$ Hasil Wawancara dengan Tgk. Nurul santri Dayah MUDI Mesra Samalanga, 12 Juli 2019

${ }^{36}$ Hasil Wawancara dengan Tgk. Dewi santri Dayah Muslimat, 13 Juli 2019

${ }^{37}$ Hasil Wawancara dengan Tgk. Maisura santri Dayah Muslimat, 13 Juli 2019
} 
merasa minder untuk kuliah di kampus. Apalagi ada kampus yang membatasi umur dalam penerimaan mahasiswa baru. Hal ini sebagaimana diungkapkan oleh teungku Fatimah sebagai berikut:

"Saya merasa minder kuliah dikampus karena usia saya yang telah lanjut, apalagi bagi kampus yang membatasi usia sudah tentu saya tidak bisa melanjutkan kuliah ke perguruan tinggi tersebut" 38

Ketakukan santri dayah terhadap informasi yang berkembang di media cetak di Aceh tentang banyaknya mahasiswa di kampus yang terpengaruh dengan aliran yang menyimpang dari ajaran Islam juga menjadi salah satu faktor penghambat bagi santri untuk melanjutkan pendidikan ke perguruan tinggi. Hal ini sebagaimana dikatakan oleh teungku Warqah sebagai berikut:

"Adanya informasi di media cetak tentang adanya aliran-aliran yang mahasiswa terpengaruh dengan aliran-aliran yang menyimpang menjadi suatu kendala bagi santri untuk melanjutkan pendidikan ke perguruan tinggi" 39

Selain persoalan di atas, kurangnya dukungan sebagian orang tua terhadap kuliah juga menjadi kendala bagi santri untuk melanjutkan pendidikan ke perguruan tinggi. Hal ini sebagaimana diungkapkan oleh teungku Hindun sebagai berikut:

"Salah satu kendala saya, dalam melanjutkan kuliah adalah kurangnya dukungan orang tua dan keluarga, karena orang tua saya yang masih kuliah masih memandang negatif kepada perguruan tinggi. Orang tua saya sangat mendukung saya untuk istiqamah di dayah" 40

Berdasarkan hasil wawancara di atas, dapat dipahami bahwa faktor penghambat santri untuk melanjutkan pendidikan ke perguruan tinggi adalah kurangnya ekonomi, ketakutan santri tentang informasi adanya aliran sesat dan kurangnya dukungan dari pihak keluarga.

Begitu juga halnya dengan konflik yang melanda Aceh beberapa tahun silam, itu menjadi faktor penghambat bagi para santri untuk melanjutkan pendidikan ke perguruan tinggi sebagaimana yang disampaikan oleh teungku Fatimah:

"Dulu saya sangat berkeinginan untuk melanjutkan kuliah ke perguruan tinggi tetapi karena Aceh dulu konflik sehingga menjadi satu hambatan bagi saya untuk tidak melanjutkan pendidikan jangankan untuk kuliah, mencari rizkipun sangat susah karena selalu berhadapan dengan aparat" ${ }^{\prime 1}$

Berdasarkan hasil wawancara di atas, penulis dapat memahami bahwa banyak teungku dayah tidak melanjutkan kuliah keperguruan tinggi karena terjadinya konflik berkepanjangan di Aceh sehingga akses mereka melanjutkan pendidikan terhambat. kedamaian di suatu daerah merupakan aset yang sangat berharga karena dengan terjadinya konflik semuanya akan terhambat baik dari segi ekonomi, sosial dan pendidikan.

\footnotetext{
${ }^{38}$ Hasil Wawancara dengan Tgk. Fatimah Dayah MUDI Mesra Samalanga, 12 Juli 2019

${ }^{39}$ Hasil Wawancara dengan Tgk. Warqah santri Dayah Muslimat, 13 Juli 2019

${ }^{40}$ Hasil Wawancara dengan Tgk. Hindun santri Dayah MUDI Mesra Samalanga, 12 Juli 2019

${ }^{41}$ Hasil Wawancara dengan Tgk. Fatimah Dayah MUDI Mesra Samalanga, 12 Juli 2019
} 


\section{Kesimpulan}

Berdasarkan pembahasan pada bab-bab sebelumnya, penulis merumuskan kesimpulan sesuai dengan rumusan masalah sebagai berikut:

1. Motivasi santriwati dayah dalam melanjutkan pendidikan ke perguruan tinggi sebenarnya sangat tinggi dikarenakan pendidikan diperguruan tinggi dapat menambah khazanah keilmuan seiring dengan tuntutan kemajuan zaman. Apalagi ada kampus yang bersedia memberikan beasiswa kepada santri yang berprestasi. Selain itu, motivasi santriwati untuk melanjutkan pendidikan di kampus, karena mereka melihat banyak orang-orang di daerahnya yang menjadi pegawai negeri sipil yang bekerja di instansi pemerintahan, mereka menggangap bahwa peluang pekerjaan harus melewati pendidikan di perguruan tinggi. Dorongan guru, orang tua dan pimpinan dayah menjadi motivasi besar bagi mereka untuk melanjutkan kuliah.

2. Persepsi santriwati dayah salafiyah Bireuen terhadap perguruan tinggi ada yang sangat positif dan ada juga yang negatif, karena persepsi mereka sangat tergantung kepada pola pikir mereka. Bagi santriwati dayah yang telah berwawasan luas memandang kampus sebagai lembaga pendidikan tinggi yang sangat dibutuhkan oleh masyarakat untuk mendidik generasi bangsa yang cerdas secara intelektual dan spritual. Namun bagi santriwati dayah yang berasumsi negatif kepada perguruan tinggi, mereka mengganggap perguruan tinggi belum mampu mendidik generasi bangsa yang bermoral dan taat dalam beragama.

3. Ada beberapa faktor yang dapat mendukung dan menghambat santriwati dalam melanjutkan pendidikan ke perguruan tinggi. Di antara faktor pendukungnya adalah adanya dukungan dan anjuran dari pimpinan untuk melanjutkan pendidikan ke perguruan tinggi. Dukungan dari orang tua dan keluarga terutama dalam bidang materil juga merupakan faktor pendukung bagi santriwati untuk melanjutkan pendidikan ke perguruan tinggi. Adapun yang menjadi faktor penghambat bagi santriwati dalam melanjutkan pendidikan ke perguruan tinggi adalah kekurangan ekonomi, usia yang lanjut, konflik yang melandai Aceh dan pemikiran santri sendiri yang telah mengikat pemikirannya untuk berkembang dan maju.

\section{Daftar Pustaka}

Alo Liliweri, Komunikasi Serba Ada Serba Makna, (Jakarta: Kencana, 2011)

Christine Daymon dan Immy Holloway, Metode-metode Riset Kulaitatif dalam Public Relations and Marketing Communications, Terj. Cahya Wiratama, Cet. I, (Yogyakarta: Bentang, 2008)

Darmiwati, Implementasi Model Pembelajaran Perubahan Konseptual Untuk Meningkatkan Prestasi Belajar, (Banda Aceh: FKIP Unsyiah, 2006)

Hadari Nawawi dan Mimi Martini, Penelitian Terapan, (Yogyakarta: Gajah Mada University Press, 1996)

Husein Umar, Metodologi Penelitian Untuk Skripsi, Thesis, dan Bisnis, (Jakarta: Grafindo Persada, 2008)

Imron Arifin, Penelitian Kualitatif dalam Ilmu-Ilmu Sosial dan Keagamaan, (Malang: Kalimasahada Press, 1996)

Komaruddin dkk, Kamus Istilah Karya Ilmiah, Cet. 1, (Jakarta: Bumi Aksara, 2000) 
M. Hasbi Amiruddin, Ulama Dayah, Pengawal Agama Masyarakat Aceh (Lhokseumawe: Nadiya Foundation, 2003)

Moleong, Metodologi Penelitian Kualitatif, (Bandung: Rosdakarya, 1997)

Mulyana, Ilmu Komunikasi Suatu Pengantar, (Jakarta: Rineka Cipta, 2001)

Muntasir, Dayah Dan Ulama Dalam Masyarakat Aceh, dalam Sarwah, Vol II,

Muslim Thahiry, dkk, Wacana Pemikiran Santri Dayah Aceh, (BRR NAD-NIAS \& Wacana Press, 2007)

Nawawi H. Hadan, Metodelogi Penelitian Bidang Sosial, (Yogyakarta: Gajah Mada University Press, 1991)

Nurcholis Madjid, Bilik-bilik Pesantren, Sebuah Potret Perjalanan, cet ke-I, (Jakarta: Paramadina, 1997)

S. Nasution, Metode Penelitian Naturalistik Kualitatif, (Bandung: Tarsito, 1988)

Suharsimi Arikunto, Prosedur Penelitian Suatu Pendekatan Praktik, (Jakarta: Rineka Cipta, 2002)

Yasmadi, Modernisasi Pesantren, Kritik Nurcholis Madjid Terhadap Pendidikan Islam Tradisional, cet ke-II (Jakarta: Quantum Teaching, 2005)

Yusny Saby, Opini Publik Terhadap Dayah, makalah yang disampaikan pada Muktamar ke-7 Persatuan Dayah Inshafuddin, Pada Maret 2004 di Banda Aceh. 